\begin{tabular}{|c|c|c|}
\hline & International Journal of Current Research in \\
Biosciences and Plant Biology \\
\hline EXCELLENT \\
PUBLISHERS
\end{tabular}

Original Research Article

doi: $\underline{\text { https://doi.org/10.20546/ijcrbp.2018.508.009 }}$

\title{
Present Situation of Cinnamon Industry in Southern Sri Lanka
}

\section{D.L.C. Kumari Fonseka*, H.N. Aluthgamage and W.W.U.I. Wickramaarachchi}

\author{
Department of Crop Science, Faculty of Agriculture, University of Ruhuna, Mapalana, \\ Kamburupitiya, Sri Lanka
}

*Corresponding author.

\section{Article Info \\ Date of Acceptance: \\ 24 July 2018 \\ Date of Publication: \\ 06 August 2018}

\begin{tabular}{l} 
Keyw ords \\
\hline Cinnamon industry \\
Cinnamon production \\
Presents situation \\
Southern province
\end{tabular}

\section{ABS TRACT}

Cinnamon belongs to Lauraceae family and to the genus Cinnamomum and Sri Lankan grown Cinnamon has a special appeal in world cinnamon trade as a result of its organoleptic properties. Sri Lanka is the largest exporter of Cinnamon with 28,320 ha under cultivation and contributes $60-70 \%$ of world true Cinnamon trade signifying its importance to local economy. The Department of Export Agriculture in collaboration with Export Development Board, Sri Lanka Chamber of Commerce, Sri Lanka Standards Institute and banks has launched a series of programmes to diversify cinnamon products and trade in the international market. In line with these developments the Department of Export Agriculture took steps to protect the status of 'true cinnamon' of Sri Lankan origin in the international market by introducing the second global brand from Sri Lanka as 'Ceylon Cinnamon'. In the wake of these new developments local cinnamon industry is undergoing a major facelift which demands a significant improvement in traditional Cinnamon production and processing system. Large portion of Cinnamon comes from the Southern province and contributes to 77\% of total domestic Cinnamon production. But $\mathrm{H} 1$ and $\mathrm{H} 2$ are the cinnamon grades that produced in highest quantities which cannot obtain a higher market price. Both the quantity and quality of Southern Cinnamon can be enhanced by well-organized government strategies regarding enhancing the productivity of nonproductive Cinnamon fields, identifying potential lands for new plantations and development of centralized processing units for Cinnamon. This article covers the present situation of Cinnamon industry in Southern Sri Lanka and provides a guidance to improve the industry from its present status.

\section{Introduction}

Ceylon Cinnamon (Cinnamomum verum Presal, Syn. C. zeylanicum), also called as true Cinnamon is a woody perennial tree species belongs to family Lauraceae. It is used worldwide as a spice, flavoring agent and for medicinal purposes since historical ages and considered as originated in the hill country of Sri 
Lanka. Cinnamon has been used as spices and medicines since ancient times and has long been held in high esteem as aromatic as well as ingredients of oils and perfumes (Krishnamoorthy and Rema, 2003). Its bark used as a spice which yields essential oil. It is helpful in the treatment of several diseases including diarrhea, nausea, vomiting, flatulence, spasmodic afflictions, asthma, paralysis, excessive menstruation, uterus disorders and gonorrhea. It provides relief from influenza and serves as a good mouth freshener. It is chiefly used to assist and flavor other drugs too (Gul and Safdar, 2009). Cinnamon helps people with type-II diabetes and improves their ability to respond to insulin, thus normalizing their blood sugar levels (Khan et al., 2003).

According to the historical evidences, Cinnamon was exported from Sri Lanka even before the $15^{\text {th }}$ century. Commercial cultivation of Cinnamon was started in the $15^{\text {th }}$ century during Dutch ruling and introduced to the Southern region of Sri Lanka (Gunaratne, 2011). Currently, Southern province is the major contributor for the domestic cinnamon production and export. Therefore, the knowledge of present situation of the Cinnamon cultivation, processing and marketing in Southern province is important for further improvement of production efficiency and quality to expand the international market for Ceylon Cinnamon. This article covers the present situation of Cinnamon industry in Southern Sri Lanka and provides a guidance to improve the industry from its present status.

\section{Materials and methods}

A detailed field survey was carried out during February to May 2017, in randomly selected 260 cinnamon lands in Galle (125), Matara (75) and Hambantota (20) administrative districts where cinnamon is mostly grown in Sri Lanka. A structured interview was carried out to collect information from farmers. Information, including productivity data, area under cultivation, types of planting materials used, extension services received, management practices, government support and the problems faced by farmers were collected by using a pre-tested questionnaire to interview the growers, and by field observations. Secondary data were collected from Performance Report, Department of Export Agriculture, 2014. Collected information were summarized and tabulated accordingly.

\section{Area under cultivation}

Southern province consists of three administrative districts as: Galle, Matara and Hambantota and Cinnamon is cultivated in all three districts (Fig. 1). Among three districts; Galle district has the highest area under cultivation followed by Matara and Hambantota districts. The area under cultivation in three districts was $11,159,8,453$ and 3,158 ha respectively. (Performance Report, Department of Export Agriculture, 2014). The cultivated area showed an increasing trend in all three districts during last ten years.

Though Galle district is having the highest land area under cinnamon cultivation, all the Cinnamon holdings are not equally productive. About $9.21 \%$ of total area under cinnamon in Galle district is reported non-productive and it comes to about 984.72 ha (District Profile, Department of Export Agriculture, Galle district, 2014). These cinnamon holdings do not contribute effectively to the total domestic cinnamon production. This situation is common for Matara and Hambantota districts though the statistics are not readily available.

Potential areas for the expansion of cinnamon cultivations can be identified in all three districts. In Galle district, potential area for mono cropping of cinnamon was reported as 1016.4 ha and another 67 ha showed the potential for intercropping with coconut in the year 2011 according to the sources of the Department of Export Agriculture (2014). But, the Department of Export Agriculture does not promote intercropping with coconut due to the prevalence of shady conditions which are not favorable for the production of high quality quills. Matara district has identified 1710 ha in Weligama and Mulatiyana areas having the highest potential for the expansion of cinnamon cultivation. In Hambantota district; Walasmulla, Katuwana, 
Okewela and Beliatta areas showed the potential for the expansion of area under cinnamon cultivation.

\section{Planting material}

Currently, seedlings are used as the main planting material for the commercial Cinnamon cultivation. Some farmers produce planting material by themselves according to the guidance of Department of Export Agriculture (DEA) and the National Cinnamon Research and Training Institute. But, majority of farmers obtain planting material from commercial nurseries. The numbers of registered cinnamon nurseries in Galle, Matara and Hambantota districts were 30, 29 and 25 respectively (DEA, 2015).

Two new varieties of Cinnamon with higher quality and yield had been introduced as Sri Wijaya and Sri Gamunu in 2009 by the Department of Export Agriculture after about twenty years of research (DEA, 2015). These two varieties needed to be cloned through rooted cuttings but this technique is still not popular among Cinnamon growers in the Southern province.

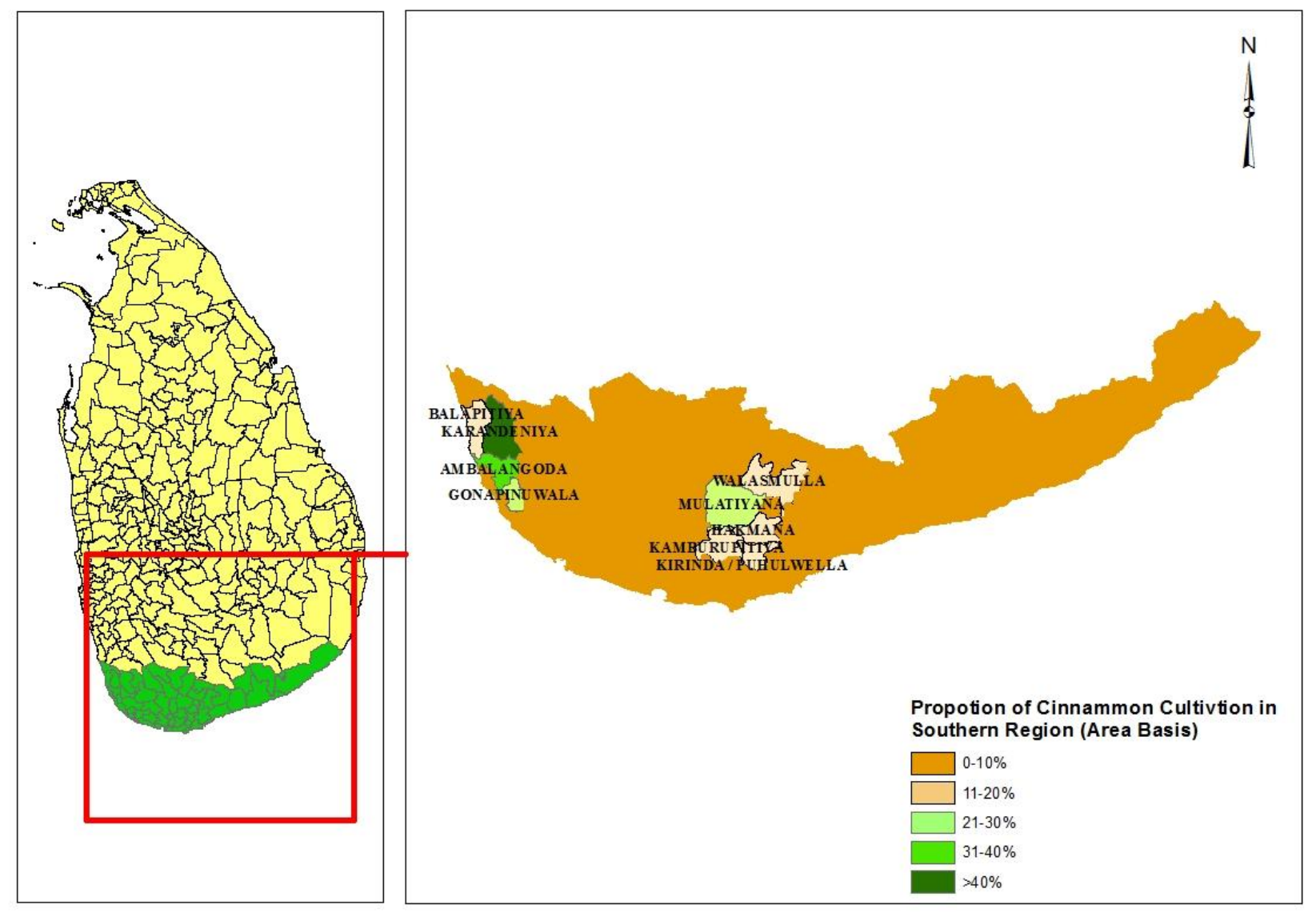

Fig. 1: Cinnamon growing areas in three districts of the Southern province.

\section{Management practices}

New cinnamon plantations are established according to the recommendations of the Department of Export Agriculture. Recommended spacing is $1.2 \mathrm{~m} \times 0.9 \mathrm{~m}$ with five seedlings per planting hole, when using seedlings. But, only three plants are planted per planting hole when rooted cuttings are used. Size of a planting hole is $30 \times 30 \times 30 \mathrm{~cm}^{3}$. Weed management is done by using cultural and mechanical methods. Agrochemicals are not recommended in Cinnamon cultivation as bark is the harvestable portion of the tree. 
Trees needed to be supported for rooted cuttings and the height of support depends on the height of the plant material. Cinnamon sticks, which remain after peeling, are commonly used for this purpose. Side branches are removed up to $30-40 \mathrm{~cm}$ from the ground level when the plants are one to one and half years old and also at three months before harvest. For rooted cuttings, side branches needed to be removed at four monthly intervals.

\section{Processing and grading of cinnamon}

Large portion of cinnamon peeling is still done by using traditional tools and equipment in the Southern province. Experienced Cinnamon peeler shortage has become a serious problem in Cinnamon industry. Hence, the Department of Export Agriculture has introduced a Cinnamon peeler training program as a self-employment project in 1988 and continued up to now. A fiveday on-the-job training was given to selected beneficiaries at divisional level. All the participants who have successfully completed the training program are provided with necessary toolkits for Cinnamon peeling. In the year 2014; 425 farmers from the Southern province had been trained as: 150 from Galle district, 183 from Matara district and 92 from Hambantota district (DEA, 2014). Mostly family labor is used for cinnamon processing in small scale cinnamon plantations (less than $1 / 2-2$ acres) while hired labor is used for large plantations which cost about $1 / 3-1 / 2$ of the total income. $\mathrm{H} 1$ and $\mathrm{H} 2$ are the cinnamon grades that produced in highest quantities in Southern province. This is mainly due to large portion of Cinnamon produced in the Southern province is exported to Mexico which has highest demand for $\mathrm{H} 1$ and $\mathrm{H} 2$ grades. $\mathrm{C} 4$ and $\mathrm{C} 5$ grades are also produced to some extent and production of Alba Grade Cinnamon is rare. Other than the demand, Cinnamon peelers tend to produce lower grade cinnamon due to ease of production.

\section{Yield and income}

According to the estimated values by the Department of Export Agriculture (2014) the highest and the lowest production of Cinnamon were observed in Galle and Hambantota districts respectively and income also varies accordingly (Table 1). These values vary according to the variation of the Cinnamon growing land extent in three districts. Southern province contributes to $77 \%$ of total domestic Cinnamon production.

Table 1. Estimated annual Cinnamon production and income of Southern province in the year 2014.

\begin{tabular}{lcc}
\hline District & Estimated annual production (Mt.) & Estimated annual income (Rs.) \\
\hline Galle & $6,686.655$ & $9,361,317.00$ \\
Matara & $6,034.77$ & $8,448,678.00$ \\
Hambantota & 816.80 & $1,143,520.00$ \\
\hline
\end{tabular}

\section{Current problems}

Most of the major problems related to Cinnamon industry in Southern province arise with the scarcity of Cinnamon peelers. To guarantee higher production of quills, harvesting of Cinnamon sticks should be done at least once per six months. But in Southern province majority of farmers harvest their Cinnamon once per eight months or once per year due to peeler scarcity. When Cinnamon sticks are over aging, the possibilities for the occurrence of pest and disease conditions become high and ability to produce higher Cinnamon grades become low.
Other than that, the productivity of land is diminishing continuously due to less number of reproductive branches at the next flush. As the final result, the farmer is unable to obtain a regular income.

In the Southern province, harvesting of most of the Cinnamon plantations is practiced on contract basis. The contractors are only focusing about their profit and they do not pay attention to the health of Cinnamon bushes. As a result, diseased branches remain in the field without getting discarded and those branches spread diseases to the newly 
emerging shoots. Eventually the level of infection is getting too high and cinnamon plantations become unprofitable.

Rough bark disease is the major disease in Southern province which spread as above and cause a huge economic loss to the farmers. This is a fungal disease which can be easily treated. But the disease is spreading in Southern province due to poor knowledge and negligence of farmers.

Though high grades fetch higher profit, production of high quality grades is rare in Southern province, except $\mathrm{H}$ grades. Major cause for this situation is over aging of cinnamon sticks. Other than that, peelers are discouraged to produce high grades due to time consuming nature of the processing of higher Cinnamon grades. In contrast, no grading is taken place at farm gate level and most often grading is practiced at exporter level. Farmers cannot obtain a premium price although they produce higher grades, therefore, both farmers and peelers do not emphasize on producing higher Cinnamon grades.

At the farm gate level, collectors used to reduce some price for the wetness though Cinnamon quills are dried to the required level. So, farmers discourage to dry cinnamon sticks properly and they sell them while moisture is present. This enhances the growth of fungus in bundles of Cinnamon quills and produce substances that can be toxic to humans.

The dominating power of the Cinnamon industry is in the hands of large scale Cinnamon exporters due to the poor involvement of the Government. Therefore, farmers have to face some social problems when they are selling their products. Farmers have to go through village Cinnamon collectors though they pay lower prices than other buyers due to the fact that they provide credit facilities to farmers when required.

Farmers obtain lower income for quills and from that $1 / 2-1 / 3$ should be given to the peelers and this leads, farmers discourage to manage their cultivation properly. With poor management the income is further diminished and these conditions go as a vicious cycle to make Cinnamon production uneconomical.

When consider about poor management practices, farmers do not apply fertilizer to their cultivations. Their attitude is Cinnamon do not require fertilizers; which is a myth. To obtain a higher production regularly, fertilization should be done continuously as recommended by the Department of Export Agriculture. But farmers apply fertilizer once and expect drastic increase of production in the next harvest; which is not realistic and they discourage to apply fertilizer afterwards. Lack of knowledge on Cinnamon nutrition is a major negative factor for the productivity of Cinnamon.

In the Southern province most of the farmers do not adapt soil conservation measures in their Cinnamon plantations. Therefore, the level of soil erosion is high in lands on slopes exposing the roots of cinnamon bushes causing very serious pest problems. Bare roots are attacked by pink stem borer finally causing break down of the stem. This can be easily prevented by adding soil to cover the base of the stem. But farmers neglect those things and productivity of the land is decreasing.

A better plant pruning is required for bush formation and management and also to obtain a harvestable stick once in six months. But no proper pruning cycle can be seen in most of the Cinnamon plantations in the Southern province. As a result, the number of depended branches becomes higher and both the yield and quality of quills become low.

Most of the farmers in the Southern province do not practice gap filling in their cinnamon plantations. This is mainly due to practical difficulties to raise plants and labor shortage. This situation increases the weed problem in the Cinnamon lands and also reduces the potential income from that land.

Cinnamon is a sun loving plant which gives maximum yield under full sun light. But most of the Cinnamon lands occupy trees which creates shady 
conditions to Cinnamon plants. Majority of those plants do not acquire any economic value but grown due to the ignorance of the farmers. Cinnamon plants tend to get blight conditions and both the quantity and quality of the products reduces as a result of shade.

Other than the poor management practices, hygienic conditions are poor in most of the processing sheds. Occasionally peelers insert immature bark fragments inside the Cinnamon sticks which become blackish with time and eventually discarded at exporter level. These problems arise due to the lack of appropriate standards and regulations and also a better inspection procedure from the government or any authorized institute. Farmers and peelers are lack in knowledge about the hygienic certifications which provides higher value to the product. There should be a regular update service from Department of Export Agriculture to aware them about the new findings and requirements.

In earlier days Cinnamon peeling was done by a certain cast and therefore, the society still has a poor attitude towards Cinnamon peelers. This discourage the young generation from selecting Cinnamon processing as a career, though it is economically viable. A central processing system which gives a better social recognition to the workers can solve this problem but such organization is still rare in the Southern province and has a magnitude impact on producing quality Cinnamon from the region.

Though government has implemented some development programs to improve Cinnamon industry, the level of engagement is not sufficient. Sri Lanka supplies $90 \%$ of the global true Cinnamon demand and the only county which is producing true Cinnamon. Therefore, have a very high potential in the international market. But still Sri Lankan Cinnamon is exported to low income countries like Mexico and not reached the European market yet. There should be a better government policy and quality control strategy which leads to enhance both quantity and quality of exporting
Cinnamon. Low quality Cinnamon is exported due to lack of proper rules and regulations.

More attention should be given to improve the productivity of existing Cinnamon lands other than expanding the land area under cultivation. Though government has implemented a productivity improvement program, its development rate is very low due to area covering per year is very low. This program has been carried out for three years but no feedback has obtained afterwards.

Even though there is a high potential for Cinnamon in the global market, government is allocating only $0.4 \%$ out of total income from export agricultural crops for the development of all export agricultural crops. If there is higher level of investment export earnings from Cinnamon can be increased proportionately and this has to take into consideration in future development plans.

\section{Government support}

Development division of the Department of Export Agriculture had carried out many successful programs during past few years and also has set targets for this year to enhance the productivity of Cinnamon. New/Replanting Program, Productivity Improvement Program and Post-Harvest Technology and quality improvement program of export agricultural crops are the major development programs among them.

Under new planting/ replanting program, seedlings are provided to new plantations and re planting of old plantations as 3,600 plants per acre up to 5 acres. Plants are obtained from the government registered private nurseries. Also a subsidy of Rs. 80,000 is given for one hectare in three installments (Table 2).

Productivity Improvement Program (PIP) was introduced to increase the production of the existing Cinnamon cultivations per unit area, where production is below the potentials due to low crop density and poor crop management. An extension officer is assigned to one village and the 
villagers are encouraged to implement a society and the subsidy is given via the society as plants and fertilizers. Cash grant (Rs. 37,500) per hectare is given in three installments as shown in the Table 2.

Target of the productivity improvement program for the year 2016 and 2017 and the progress of the extent developed under productivity improvement program are given in the Table 3 . The main objective of the assistance scheme for post-harvest development activities is to maintain the quality of the product to be competitive in international markets, product diversification and value addition to facilitate marketing of export agricultural crop products. For processing sheds, a subsidy of Rs. 100,000to Rs. 200,000 can be obtained according to the area which varies from $400 \mathrm{ft}^{2}$ to $1000 \mathrm{ft}^{2}$. A leaf oil unit with the capacity higher than $250 \mathrm{~kg}$ and a bark oil unit with the capacity higher than $50 \mathrm{~kg}$ can obtain a subsidy of Rs. 250,000.for encouraging farmers to product diversification.

Table 2. Time schedule for the new planting/ replanting subsidy and assistance scheme for productivity improvement program (Cash grant per hectare).

\begin{tabular}{llll}
\hline \multicolumn{2}{l}{ Time schedule for the new planting/ replanting subsidy } & \multicolumn{2}{l}{ Assistance scheme for productivity improvement } \\
\hline \multirow{2}{*}{ Time from establishment } & $\begin{array}{l}\text { Amount of the Subsidy } \\
\text { (Rs.) }\end{array}$ & Time from establishment & $\begin{array}{l}\text { Cash grant/ hectare } \\
(\text { Rs. })\end{array}$ \\
\hline 3 months & $40,000.00$ & $1^{\text {st }}$ year & $13,000.00$ \\
$11 / 2$ years & $20,000.00$ & $2^{\text {nd }}$ year & $13,000.00$ \\
$21 / 2$ years & $20,000.00$ & $3^{\text {rd }}$ year & $11,500.00$ \\
\hline
\end{tabular}

Table 3. Developed extent and target in (ha) for 2016 and 2017.

\begin{tabular}{lllll}
\hline District & $\begin{array}{l}\text { Target (ha) } \\
\mathbf{2 0 1 6}\end{array}$ & $\begin{array}{l}\text { Developed Extent (ha) } \\
\mathbf{2 0 1 6}\end{array}$ & $\begin{array}{l}\text { Target (ha) } \\
\mathbf{2 0 1 7}\end{array}$ & $\begin{array}{l}\text { Developed Extent (ha) } \\
\text { August 2017 }\end{array}$ \\
\hline Galle & 180 & 160 & 180 & 18 \\
Matara & 130 & 160 & 130 & 12.65 \\
Hambantota & 40 & 32.8 & 75 & Will be started in Maha season \\
\hline
\end{tabular}

\section{Conclusion}

At present, the total area under Cinnamon in Southern province is 22,720 ha which gives an annual production of $13,538.255 \mathrm{Mt}$. The potential bark yield is about $1,200 \mathrm{~kg} / \mathrm{ha}$ under well managed Cinnamon plantation though we obtained about 500 $-600 \mathrm{~kg} / \mathrm{ha}$ ( $200-250 \mathrm{~kg} / \mathrm{acre})$. Therefore, we have a huge potential to increase the production of the current Cinnamon plantations and the potential yield is about 27,264 Mt. Both the quantity and quality of Southern Cinnamon can be enhanced by well-organized government strategies regarding enhancing the productivity of nonproductive Cinnamon fields, identifying potential lands for new plantations, regular extension service and development of a central processing system for processing of Cinnamon with higher grades and low production cost. Establishing central processing unit/units will reduce the production cost and increase the farmer income while supplying quality 'Ceylon Cinnamon' to the export market keeping the brand Ceylon Cinnamon in a better position.

\section{Conflict of interest statement}

Authors declare that they have no conflict of interest.

\section{Acknowledgement}

Authors acknowledged the support and information provided by the National Institute of Cinnamon Research and Training, Department of Export Agriculture Regional offices and farmers involved in interviews in Galle, Matara and Hambantota. 


\section{References}

Department of Export Agriculture (DEA, 2005). Annual Performance Report, Ministry of Minor Export Crop Promotion, Sri Lanka.

Department of Export Agriculture (DEA, 2006). Annual Performance Report, Ministry of Minor Export Crop Promotion, Sri Lanka.

Department of Export Agriculture (DEA, 20072009). Annual Performance Report, Ministry of Minor Export Crop Promotion, Sri Lanka.

Department of Export Agriculture (DEA, 2010). Annual Performance Report, Ministry of Minor Export Crop Promotion, Sri Lanka.

Department of Export Agriculture (DEA, 20112013). Annual Performance Report, Ministry of Minor Export Crop Promotion, Sri Lanka.

Department of Export Agriculture (DEA, 2014). Annual Performance Report, Ministry of Minor Export Crop Promotion, Sri Lanka.

Department of Export Agriculture (DEA, 2015).
Annual Performance Report, Ministry of Minor Export Crop Promotion, Sri Lanka.

District profile, Galle district, Sri Lanka. 2014. Department of Export Agriculture, Ministry of Minor Export Crop Promotion, Sri Lanka.

Gul, S., Safdar, M. 2009. Proximate composition and mineral analysis of cinnamon. Pak. J. Nutr. 8(9), 1456-146.

Gunaratne, W. D. L. 2011. Current situation and future trends of Cinnamon industry, Proceedings of the International Symposium: Technology to reach future aspirations of Ceylon Cinnamon, 05 - 08.

Khan, A., Safdar, M., Khan, M.M.A., Khattak, K.N. and Anderson, R.A. 2003. Cinnamon improves glucose and lipids of people with Type II diabetes. J. Diabetes Care, 26: 32153218.

Krishnamoorthy, B. and Rema, J. 2003. End uses of Cinnamon and Cassia [online] available at: https://books.google.lk

\section{How to cite this article:}

Kumari Fonseka, D.L.C., Aluthgamage, H.N., Wickramaarachchi, W.W.U.I., 2018. Present situation of cinnamon industry in Southern Sri Lanka. Int. J. Curr. Res. Biosci. Plant Biol. 5(8), 63-70. doi: https://doi.org/10.20546/ijcrbp.2018.508.009 